\title{
RT-PCR Based Cloning And Sequencing Of Potato Leaf Roll Virus-Coat Protein (PLRV-CP) Gene For Characterization As A Bangladeshi PLRV Isolate And Its Phylogenetic Analysis
}

\author{
Md. Belal Hossain, Tanjila Hasan, Ibne-Siam-Joy, Ratna Akter, and Saleh Ahmed Shahriar
}

\begin{abstract}
An experiment was conducted in Molecular Biology and Plant Virology Laboratory under the Department of Plant Pathology, Sher-e-Bangla Agricultural University, Dhaka-1207, Bangladesh. Total RNA was extracted from Potato leaf roll virus (PLRV) positive leaves and complementary DNA (cDNA) were synthesized from total RNA. Reverse transcriptase polymerase chain reaction (RT-PCR) based detection conditions were optimized by using coat protein $(\mathrm{CP})$ gene specific primers. In PCR amplification cDNA and in nucleotide sequencing PCR product was used as a template. A 346 bp amplicon of PLRV$C P$ gene was amplified and amplified gene region was sequenced. The expected nucleotide sequence of amplified PLRV-CP gene showed 95 to $\mathbf{9 8 \%}$ homology when compared with the isolates sequences reported in Gene Bank database. This explored novel PLRV-CP gene was characterized as a PLRV Bangladeshi isolate (Accession number, Bankit 2274496, MN605963). PLRV-CP gene protein modeling was carried out using Expert Protein Analysis System (ExPaSy), DNASTAR's protein tools server used for 3D protein modeling. Phylogenetic analysis was also carried out, the tree was made by using MEGA 4.0 software and maximum parsimony method was selected to construct phylogenetic tree. The RT-PCR based molecular technique optimized in this study, would be a useful for early detection, epidemiological studies of PLRV as well as in seed tubers certification program and the novel hyper variable sequenced region of PLRV-CP gene will be useful in pathogen derived resistance breeding program against the PLRV local strain.
\end{abstract}

Index terms-Potato, PLRV-CP Gene, PCR-Based Cloning, PLRV-Bangladeshi isolate.

\section{INTRODUCTION}

Potato (Solanum tuberosum L.) is the most important food crops in the world including Bangladesh, as a food crop, potato's position in fourth next to wheat, rice and maize. The potato tuber is an excellent source of carbohydrates, protein and vitamins [1]. In comparison to other agricultural crops, the seed cost of potato cultivation is much higher that is liable to $30-40 \%$ of total production cost. Developing countries like Bangladesh, imported high yielding foreign potato varieties from other countries/regions with the high cost. High yielding foreign potato varieties may be significantly increased the yield of potato crop but at the same time resulted new viral problems transpires like PLRV, $P V Y$ and $P V X$, sometime which causes $10-90 \%$ yield losses and have been increased the seed cost of potato cultivation once more. So in developing countries, viral diseases are one of the major causes of increasing the potato cultivation cost as well as low yield. Their control requires the development of appropriate, sensitive and reliable detection methods along with the study about their persistence in various plant parts [2]. Potato leaf roll virus $(P L R V)$ causes devastating effects on potato production. This virus initially affects the aerial parts of potato plant causing the stem and apical leaves to roll. The diseased plants produce fewer and smaller tubers than the normal plants resulting in significant yield reduction and some varieties may show "net necrosis". PLRV differs from other potato viruses, because it is exclusively found in phloem tissues and causes necrosis and abnormal callose accumulation in the vascular system. $P L R V$ is a persistent virus and vectored by several aphid species; the green peach aphid (Myzus persicae) is the most important one of them [3]. $P L R V$ is distributed worldwide in potato growing areas. Quality of seed tubers is badly affected due to the development of phloem necrosis. The serological methods can be unreliable for $P L R V$ detection, because this virus often occurs at low concentration in plant tissue and virions are weakly immunogenic [4]. So far, no published information is available regarding the $P L R V-C P$ gene sequences of Bangladeshi isolate. The specific objectives of the study was; to detect and characterize the PLRV through RT-PCR amplification, and PCR-based cloning, sequencing of PLRV$C P$ gene for characterization as a Bangladeshi isolate. Through this study, a reliable RT-PCR based molecular detection method was developed for local strain of PLRV and a Bangladeshi isolate of $P L R V$ was found on the basis of nucleotide sequencing. The sequence identity analysis of the PCR-Based cloned PLRV -CP gene was used to assess homologies among several $P L R V$ isolates reported in Genbank database.

\section{METHODOLOGY}

Total RNA was extracted from $P L R V(+)$ ve potato leaves, showing typical symptoms; the stem and apical leaves to upward rolling and yellowing. Leaves were collected in liquid $\mathrm{N}_{2}$ flask and ground to fine powder with cooled mortar and pestle. Ground samples were taken in $1.5 \mathrm{ml}$ eppendorf tubes then added $1 \mathrm{ml}$ TRIzol @ approximately per $0.2 \mathrm{~g}$ of leave powder samples and kept at room temperature for 5-10 minutes for completely detachment of nucleoprotein fused. After that tubes were shaking for 30-45 seconds and added $0.2 \mathrm{ml}$ chloroform per $1 \mathrm{ml}$ of TRIzol in tube, then again it was kept at room temperature for 5-10 minutes. After incubation, tubes were centrifuged at $13,000 \mathrm{rpm}$ for 15 minutes at $4^{\circ} \mathrm{C}$. The centrifuged solution having RNA rich upper portion was transferred into new eppendorf tubes. RNA was achieved by pouring $0.5 \mathrm{ml}$ isopropanol in new tubes by precipitation. After pouring the isopropanol, incubation time 
was given to tubes for 10 minutes followed by centrifugation for 10-12 minutes at $4^{\circ} \mathrm{C}$ with $13000 \mathrm{rpm}$. After centrifugation, supernatant was removed and pellet was washed by adding $1 \mathrm{ml} 75 \%$ ethanol. The sample was resuspended properly through pipetting and centrifuged at $4^{\circ} \mathrm{C}$ with 10,000 for 5-6 minutes. Then remove supernatant and air dry the RNA pellet for 10 minutes. DEPC treated water $(20 \mu \mathrm{l})$ was used to re-suspend the dried RNA and put at $-20^{\circ} \mathrm{C}$ immediately. RNA quality was confirmed in agarose gel (1\%).

Complementary DNA (cDNA) was synthesized using "First Strand cDNA Synthesis kit" (Thermo) and followed the protocol provided with kit. According to protocol, adding $1 \mu \mathrm{g}(4 \mu \mathrm{l})$ of the total RNA then added $1.0 \mu \mathrm{l}$ of the reverse primer (10 pmoles) and added nuclease-free water to make volume upto $11 \mu 1$ then spun gently in a micro-centrifuge for 5-10 seconds. After incubation at $70^{\circ} \mathrm{C}$ for 5 minutes and transfer into ice. After ice chilling for few minutes, added $4 \mu \mathrm{l}$ reaction buffer $(05 \mathrm{X}), 1 \mu \mathrm{l}(20 \mathrm{u} / \mu \mathrm{l})$ Ribonucleaseinhibitor and $2 \mu \mathrm{l}$ of $10 \mathrm{mM}$ dNTPs mix $(20 \mathrm{u} / \mu \mathrm{l})$ then incubation at $42^{\circ} \mathrm{C}$ for 5 minutes and added $02 \mu 1$ (M$\mathrm{MuLV} 20 \mathrm{u} / \mu \mathrm{l})$ reverse transcriptase for volume of $20 \mu \mathrm{l}$ reaction. Finally, incubation at $42^{\circ} \mathrm{C}$ for 60 minutes and before stopping the reaction incubation at $70^{\circ} \mathrm{C}$ for 5 minutes and ice chilling at once.

For optimization of annealing temperature of designed primers; PLRV-346-Forward Primer, 5'CAGGCGCCGAAGACGCAGAA-3' and PLRV-346Reverse Primer, 5'-TTTGGCGCCGCCCTTCGTAA-3', to detect the PLRV local strain, Gradient PCR was run. cDNA was used as template in PCR reaction. Total volume of $20 \mu \mathrm{l}$ PCR reaction was as follows- $2 \mu 1$ 10X PCR buffer, $2 \mu 11 \mathrm{mM}$ dNTPs, $2 \mu \mathrm{l}$ FP (10pmoles) \& $2 \mu \mathrm{l}$ RP (10pmoles), $4 \mu 1$ cDNA, $0.5 \mu 1$ Taq polymerase and added PCR $\mathrm{H}_{2} \mathrm{O}$ to make the reaction volume $20 \mu \mathrm{l}$. PCR amplification was performed by 35 cycles after initial denaturation at $94^{\circ} \mathrm{C}$ for 4 minutes in a thermal cycler starting with denaturation at $94^{\circ} \mathrm{C}$ for 1 min, primer annealing at $55^{\circ} \mathrm{C}$ for $1 \mathrm{~min}$ and extension at $72^{\circ} \mathrm{C}$ for $1 \mathrm{~min}$ followed by final extension at $72^{\circ} \mathrm{C}$ for 10 minutes. The PLRV-CP gene was sequenced using primers (forward/reverse) respectively. Sequencing reaction set-up was performed as follows; $2.0 \mu \mathrm{l}$ Template (Purified PCR product), $1.5 \mu \mathrm{l}$ Forward/ Reverse primer, $1.5 \mu$ l sequencing buffer (5X), $1.0 \mu$ l Bigdye and added $\mathrm{PCR} \mathrm{H}_{2} \mathrm{O}$ to make final $20 \mu 1$ reaction volume. Sequencing PCR was also performed by 35 cycles after initial denaturation at $96^{\circ} \mathrm{C}$ for $20 \mathrm{sec}$ in a thermal cycler starting with denaturation at $96^{\circ} \mathrm{C}$ for $20 \mathrm{sec}$, primer annealing at $55^{\circ} \mathrm{C}$ for $20 \mathrm{sec}$ and extension at $60^{\circ} \mathrm{C}$ for $4 \mathrm{~min}$ followed by final extension at $60^{\circ} \mathrm{C}$ for $4 \mathrm{~min}$. Expert Protein Analysis System (ExPaSy) was applied to convert the DNA sequence into protein amino acid by prediction. In 6 frame results, we selected first 5'-3' frame protein sequence with lowest number of stop codons and position of stop codon in this sequence at 3' end. That sequence was also provided to DNASTAR's protein tools, a 3D protein modelling server. Protein sequence was aligned with other proteins sequence to find out the best and most suitable functional 3D molecular structure of our PLRV coat protein. Structure with maximum homology was used as template for modelling. Homology studies were done through standard nucleotide-nucleotide BLAST (Basic Local Alignment Search Tool) software. The multiple sequence alignment was done using Cluster W multiple sequence alignment programs integrated in
MEGA7.0 [5]. Phylogenetic analysis was done by MEGA 7.0 integrated with maximum parsimony method to construct phylogenetic tree [6]. At first selected "consensus tree" and then software returned the given phylogenetic reconstruction tree via "compute tree" option of the software.

\section{RESULTS AND DISCUSSION}

The PCR product was separated on agarose gel $(1.5 \%$, stained with $(0.5-1 \mu \mathrm{g} / \mathrm{ml})$ ethidium bromide. Amplified fragments of $P L R V$ was analyzed along with 50 bp DNA marker and visualized under UV light. The results are presented as figure 1. The amplified fragments were cut for elution using DNA Gel elution kit (Thermo). The PCR product, for nucleotide sequence, was also analyzed on agarose gel (1.5\%) along with 50 bp DNA marker. The results are presented as figure 2 . First objective of the study, was to develop a RT-PCR based detection protocol of PLRV local strain for commercial purposes. Because RT-PCR provides great sensitivity than molecular hybridization like ELISA, it is a good alternative to other diagnostic methods with high speed diagnosis and requires reduce sample size. The availability of nucleotide sequences of many plant pathogens has made possible the development of PCR assays for the detection and diagnosis of several viruses and other pathogens. The RT-PCR has also been successfully utilized for the detection of plant viruses for example, Grapevine virus $A(G V A)$ from infected grapevine, apple scar skin and pome fruit virus and Potato virus $A(P V A)$ in dormant tubers $[7,8,9]$. Potato virus $S$ (PVS), Potato virus $X(P V X), P L R V$, Potato virus $A$ and $Y(P V A$ and $P V Y)$ and Potato spindle tuber viroid ( $P S T V d)$, these five potato viruses has been detected simultaneously through Multiplex-RT-PCR $[10,11]$. So far, Real time PCR has also been described for efficient detection of PLRV from dormant potato tubers [12]. But due to high costs of equipment and molecular reagents involved in real time PCR, the method laboring in the present study is more applicable and cost-effective. The RT-PCR-based assay can also be considered as a potential method for routine diagnosis because of its less time-consumption and higher sensitivity [13].

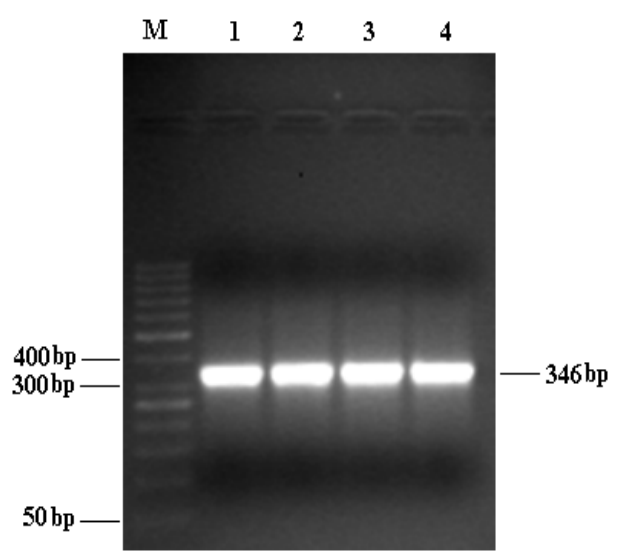

Figure 1: Amplification of $P L R V-C P$ gene through RT-PCR. M depicts 50bp DNA Ladder while Lane 1-4 show PLRV-CP gene amplification 


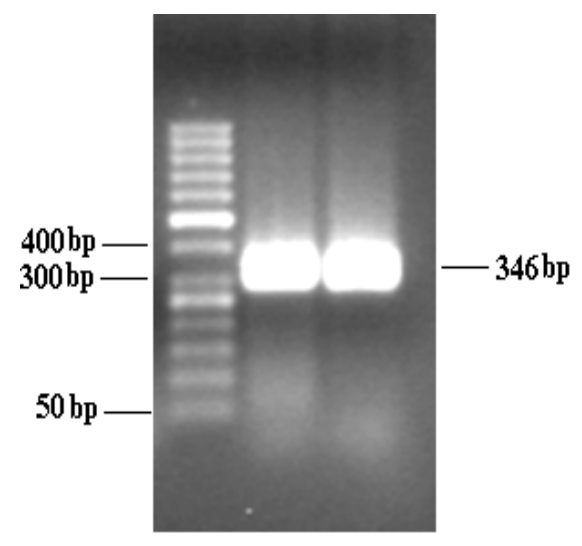

Figure 2: PCR product for nucleotide sequencing that analyzed on $1.5 \%$ agarose gel along with 50 bp DNA marker

Automated DNA sequencing system from applied Biosystems was used along with ABI PRISM genetic analyzer. The data was provided as fluorimetric scans form which the sequence was assembled using the Sequence Navigator software. Newly sequenced $P L R V-C P$ gene was submitted to NCBI GenBank through Bankit and NCBI GenBank authority has been verified the submitted gene sequence and assigned the accession number (Bankit2274496, MN605963). The submitted FASTA form of gene sequence, submission record and GenBank database with assigned accession number of the submitted gene sequence are given below-

$>$ seg1 Potato leaf roll virus (PLRV), coat protein gene (CPgene),partial sequence

CAACGTCGAGGTAGGTCGAGAACTCGAATTCTGTT CACACATCTTCAGAATTCCGACCCTCGCCGTTCCGG TCAATACCAACAAAATGCTTTACAAGTTGATCCAT GGTTATAATCCGGAATGTGGCAATCCAGAAGTGAT TCAAAACTATCTGGCTGCAGTATTCTCTGTGCTGCA CGAGCTCAGACACGATCGTGAGCTCGTTGCCAAGC TCCACCAGTGGTTGGTTCCGAGTGCCACCACAAAA GAACACTGAAGGAGCTCACTAAAACTAGCCAAGC ATAAGCGAGTTGCAAGCATTGGAAGTTCAAGCCTC GTTACATCAACCGGACAAATTAGATAATAA

3D structure, with alpha helix and beta sheets was deduced by the server (DNASTAR's protein tools). Different amino acids are showed with different color according to their characteristics. Another structure showing molecular surface of active protein in solution was predicted and illustrated (Figure 3).

5'-3' Frame

NVEVGRELEFCS H I F R I P T L A V P V N T N K M L Y K L I H G Y N P E C GN P E VIQN Y L A A V F S V L H E L R H D R E L V A K L H Q W L V P S A T T K E H R S S L K L A K H K R V A S I G S SS L V T S T G Q I R

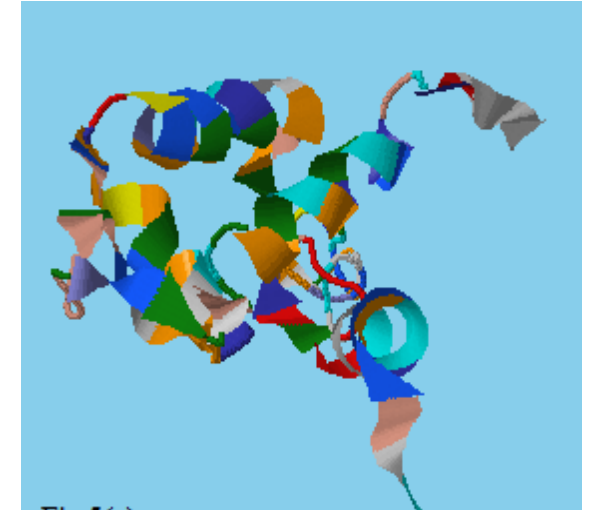

Figure 3: 3-D structure of PLRV-coat protein with alpha helix and beta sheet

Multiple sequences alignments were done with the nucleotide sequence of PLRV-CP gene of a Bangladeshi isolate (Bankit2274496 Accession No. MN605963) and obtained considerable similarity with the other members of Luteoviridae family. This $P L R V-C P$ new isolate exhibit its maximum homology (98\%) with one complete sequence (Accession No. KP090166.1) and one partial (China isolate, Accession No. MF589765.1). Scottish isolate (Accession No. EU717546.1) and Indian isolate (Accession No. GU256062.1) showed 97\% homology and Australian isolate (Accession No. D13953.1) showed 96\% homology with new Bangladeshi isolate. While other isolates, reported in genbank data based, were showed $95-97 \%$ homology. That similarity was also viewed in the phylogenetic tree developed from multiple sequence alignment (Figure 4). There was not too much diversity among the globally found $P L R V$ isolates. High similarity with other isolates depicts that $P L R V-C P$ gene sequence of Bangladeshi isolate is also highly conserved among PLRV isolates sequences reported in GenBank databases and sequence can be used efficiently in molecular detection of this virus. The Second objective of the study was sequence comparison and explore the homology through multiple sequences alignments and phylogenetic analysis. In the present study, the total $346 \mathrm{bp}$ size coat protein gene of $P L R V$-CP gene was amplified and sequenced. The homology of sequenced gene was studied with the already reported sequences in the Genbank database through multiple sequence alignment as well as phylogenetic analysis. From the both bioinformatics studies, it was found that the PLRV$C P$ gene sequence as Bangladeshi isolate is strongly related with all reported isolates of $P L R V$ in GenBank databases. It means sequence gene is relatively conserved with $P L R V$ genome that is analogous to previous reports [14]. High homology was observed with some European isolates as well as with few China isolates and somewhat distant relationship was observed with Scottish isolates, Indian isolates and Australian isolates. Recent two reports; Indian isolate match with the present findings when compared with the nucleotide sequence and the deduced amino acid sequence [15] and Egyptian isolate of Luteoviruses was also found to match at the nucleotide level [16]. 


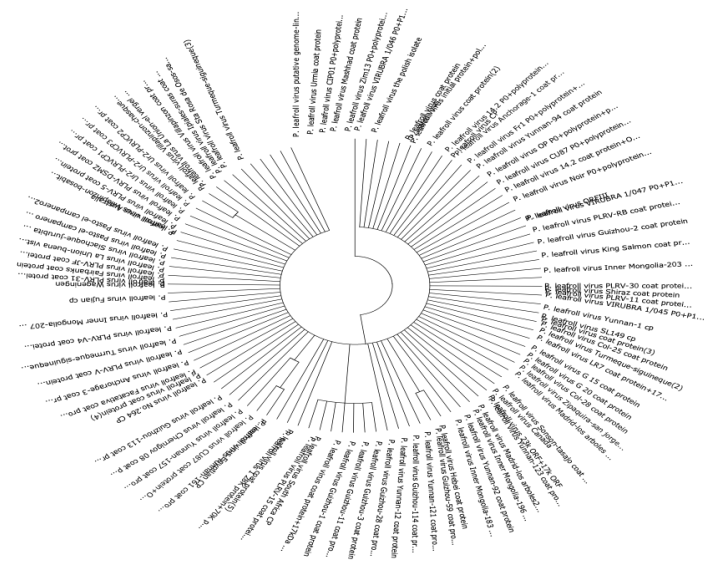

Figure 4: Phylogenetic tree generated by MEGA 7.0 and Maximum Parsimoney method. All the globally found $P L R V$ isolates were very closely related to each other as shown in the tree.

\section{CONCLUSION}

From the study, it may concluded that this RT-PCR based molecular technique would be a useful for epidemiological studies of $P L R V$. This developed protocol can be used for seed tubers certification program in Government agencies of Bangladesh as well as early detection of $P L R V$ in potato field. On the other hand, the portion of $P L R V$-CP gene sequenced in the present study showed homology within the range of 95 to $98 \%$ with others $P L R V$ isolates sequences reported in GenBank databases and did not show $100 \%$ homology with any one of the reported isolates. So, it is proved that this sequence may not have been reported before from Bangladesh as well. The newly sequenced PLRV-CP gene was submitted to NCBI GenBank and GenBank authority assigned the accession number (Bankit2274496 MN605963) as a first report of PLRV isolate from Bangladesh (Bangladeshi isolate). However, finally it may concluded that the novel gene and hyper variable sequence region of $P L R V$ $C P$ gene be explored, which may play a vital role in pathogen derived resistance breeding program.

\section{REFERENCES}

[1] M. Gillivray and P. A. Minges, "Conveyor Belts speed potato harvest, American Vegetable Grower," Vol.1, pp. 11-21, 1953.

[2] L. F. Salazar. (1994). Virus detection and management in developing countries. In advances in potato pest biology and management. Edited by G.W. Zehnder, M.L. Powelson, R.K. Jansson and K.B. Raman, APS Press, St. Paul, Minn.

[3] D.M. Spooner, K. Mclean, G. Ramsay, R. Waugh, and G. J. Bryan. (2005). A single domestication for potato based on multilocus amplified fragment length polymorphism genotyping. PNAS, 102 (41), pp 14694-14699.

[4] A.B.R. Beemster and J.A. De Bokx. (1987). Survey of properties and symptoms. In: Viruses of Potatoes and Seed-Potato Production. (Eds.): J.A. de Bokx and J.P.H. van der Want. Pudoc, Wageningen (NL), pp 84-113.

[5] M.A. Larkin, G. Blackshields, N.P. Brown, R. Chenna, P.A. McGettigan, H. McWilliam, F. Valentin, I.M. Wallace, A. Wilm, R. Lopez, J.D. Thompson, T.J. Gibson, and D. G. Higgins. (2007). Clustal W and Clustal X version 7.0. Bioinformatics, 23, pp 29472948.

[6] K. Tamura, J. Dudley, M. Nei, and S. Kumar. (2007). MEGA4: Molecular Evolutionary Genetics Analysis (MEGA) software version 4.0. Mol. Biol. Evol. 24, pp 1596-1599.

[7] R. P. Singh and M. Singh (1998). Specific detection of potato virus A in dormant tubers by reverse transcription polymerase chain reaction. Plant Dis. 82, pp 230-234.

[8] A. Haididi, M.S. Montessori, L. Levy, R.W. Goth, R.H. Converse, M.A. Madkour, and L. J. Skrzeckowski. (1993). Detection of potato leaf roll and strawberry mild-yellow-edge luteoviruses by reverse transcriptase polymerase chain reaction amplification. Plant Dis. 77, p 595 .

[9] A. Minafra, A. Haididi, and G.P. Martelli. (1992). Detection of grapevine closterovirus A In infected grapevine tissue by reverse transcriptase polymerase chain reaction. Vitis. 31, p 221.

[10] X. Nie and R.P. Singh. (2000). A novel usage of random primers for multiplex RT-PCR detection of virus and viroid in aphids, leaves, and tubers. J. Virol. Methods. 91, pp 37-49.

[11] B. O. Agindotan, P.J. Shiel, and P. H. Berger. (2007). Simultaneous detection of potato viruses, $P L R V, P V A, P V X$ and $P V Y$ from dormant potato tubers by TaqMan ${ }^{\circledR}$ real-time RT-PCR. J. Virol. Methods. 142, pp 1-9.

[12] S.M. Mortimer-Jones, G.K.M. Jones, A.C.R. Jones, G. Thomson, and G.I. Dwyer. (2009). A single tube, quantitative real-time RT-PCR assay that detects four potato viruses simultaneously. J. Virol. Methods. 161, pp 289-296.

[13] C.D. Schoen, D. Knorr, and G. Leone. (1996). Detection of potato leaf roll virus in dormant potato tubers by immunocapture and fluorogenic 5' nuclease RT-PCR essay. Phytopathology, 86, pp 993-999.

[14] P. Kesse, R.R. Martin, L.M. Kawchuk, P.M. Waterhouse, and W.L. Gerlach. (1990). Nucleotide sequences of an Australian and a Canadian isolate of potato leaf roll luteovirus and their relationships with two European isolates. J. Gen. Virol. 71, pp 719-724.

[15] K. Mukharjee, V. Yogita, K.C. Swarup, M.N. Singh, and S.M. Paul Khurana (2003). Cloning and Sequencing of Coat protein gene of an Indian Potato Laef Roll Virus (PLRV) isolate and its similarity with other members of Luteoviridae. Virus Genes, 26(3), pp 247-253.

[16] A.K. El-Attar, B.Y. Riad, A. Saad, A.M Soliman, and H.M. Mazyad. (2010). Expression of the coat protein gene of potato leaf roll virus in Escherichia coli and development of polyclonal antibodies against recombinant coat protein. Arab J. Biotechnol. 13(1), 85-98.

\section{ACKNOWLEDGMENT}

This research work is financed by Bangladesh Academy of Science-Unitate State Department of Agriculture (BAS-USDA) to Prof. Dr. Md. Belal Hossain, research grants agreement No.-BAS-USDA PALS SAU CR-04. The research group remains indebted to BAS-USDA for research grants and also indebted to Sher-e-Bangla Agricultural University Research System (SAURES) for smooth supporting during the study program. Research team also thankful to the Department of Plant Pathology, Sher-e-Bangla Agricultural University, Dhaka-1207, Bangladesh for creating an enabling environment to success this piece of research work.

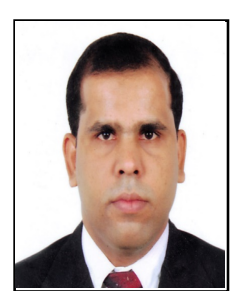

Dr. Md. Belal Hossain was born in a respected muslim family under Upazilla and District Thakurgaon on $21^{\text {st }}$ August, 1980 in Bangladesh. He has completed B.Sc.Ag (Hons.) and MS in Plant Pathology from Sher-e-Bangla Agricultural University, Dhaka, Bangladesh. After completion his MS Degree he joined as a Lecturer in the same Department \& University in 2006. After completion his lecturer tenure he has got promotion as Assistant Professor in 2008. He has completed his $\mathrm{PhD}$ in Molecular Biology in 2014 under CEMB-TWAS Postgraduate Fellowship programme'2008. After successful completion of his $\mathrm{PhD}$, he was backed in Bangladesh and joined the same Department and University as Assistant Professor. He got promotion as Associate Professor in 2014 and Professor in 2018. Now he is working as Professor in the Department of Plant Pathology, Sher-e-Bangla Agricultural University, Dhaka, Bangladesh. He has attended many international seminar, symposium, workshop and conference. He has published many scientific papers in different national and international peerreview indexing and impact factor journals. He is also the editor and reviewer of national and international peer-review journals. 